\title{
Analysis of mechanical properties of transition segment of road and bridge based on high-strength foam concrete
}

\author{
Hongmei CaO \\ Sichuan College of Architectural Technology, Deyang, Sichuan 618000, China \\ bongmc_hm@aliyun.com
}

\begin{abstract}
The settlement difference in the transition section of road and bridge may lead to traffic accidents, which has many negative effects. Back filling of foam concrete behind abutment is a good method of treatment. In this study, a kind of high-strength foam concrete was designed for back filling of transition section of road and bridge, and the mechanical properties of the transition section of road and bridge were analyzed using finite element analysis method. It was found that only a large number of micro cracks grew in high-strength concrete under a large number of load cycles, and structural damage did not happen, indicating the high-strength foam concrete had high strength and long service life; the static base pressure was about $40 \mathrm{kPa}$, indicating a small burden on the structure. Under the vehicle load, the vertical displacement of the transition section of road and bridge with back filling of high-strength foam concrete behind abutment was about $0.7 \mathrm{~m}$ and the maximum vertical stress was about $-40 \mathrm{kPa}$, which was significantly lower than that of the ordinary concrete, and the stability was favourable and the settlement was small, indicating that the high-strength foam concrete had good vibration absorption effect. The analysis results verifies the value of the high-strength foam concrete as the backfill material of the transition section of road and bridge and proves that it can effectively solve the problem of differential settlement of the transition segment of road and bridge, providing some theoretical bases for its application and popularization.
\end{abstract}

KEYWORDS. Foam concrete; Transition section of road and bridge; Settlement difference; Back filling behind abutment; Mechanical properties.

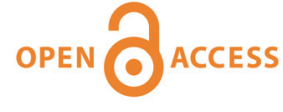

Citation: Cao, H.M., Analysis of mechanical properties of transition segment of road and bridge based on high-strength foam concrete, Frattura ed Integrità Strutturale, 49 (2019) 831-839.

Received: 21.01 .2019

Accepted: 29.04.2019

Published: 01.07.2019

Copyright: (C) 2019 This is an open access article under the terms of the CC-BY 4.0, which permits unrestricted use, distribution, and reproduction in any medium, provided the original author and source are credited.

\section{INTRODUCTION}

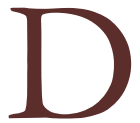

ifferential settlement of transition segment of road and bridge is a common problem. Soft soil foundation in coastal areas is prone to deformation, which will result in the compression of filling behind abutment and settlement difference problem. The rigidity difference between abutment and roadbed will also cause settlement difference [1]. Abutment which has large rigidity has small settlement, but roadbed which has loose filling is easy to 
deform and cause settlement. The settlement difference in the transition segment of road and bridge will make vehicles bump when passing; the faster the vehicle speed, the stronger the vibration [2], which will not only make the driver and passenger feel uncomfortable, but also damage car components and increase fuel consumption, even causing traffic accidents. Vehicle bumping will also bring great impact to the transition section of road and bridge, especially at the expansion joint of bridge deck, which will damage bridge deck and roadbed [3], affect the stress distribution of pavement [4], increase the human and financial resources in pavement maintenance, and seriously affect the service life of pavement [5], i.e., have negative effects in aspects of economics and safety. How to effectively solve the problem of settlement difference and ensure driving stability is of great significance [4] and has become a major problem in engineering construction [7]. At present, there are many methods to solve the settlement difference problem in China and abroad, such as using bridge end transition slab [8], i.e., connecting bridge abutment with roadbed through reinforced concrete slab [9], improving the degree of density of roadbed and reducing deformation by using civil engineering material with reinforced bars and loading preload, increasing rigidity of foundation by piling, and filling foundation with lightweight materials. Greco et al. [10] regarded vehicle and bridge as an integrated system based on moving mesh strategy and analyzed the moving load of vehicle and bridge interaction using finite element model. Lonetti et al. [11] analyzed the dynamic properties of tied-arch bridge under the action of moving load and evaluated the interaction between deformation of bridge and moving load, including the impact of the external quality of mobile system on dynamic bridge. Sun et al. [12] suggested application of deep reinforced concrete plate to solve the differential settlement of transition segment of road and bridge and found that the method had great advantage in controlling settlement and could effectively reduce bump at bridge-head through finite element analysis. Liu et al. [13] made a finite element analysis of the pavement settlement and stress change of the transition section of road and bridge under dynamic and static loads and found that the maximum stress decreased significantly, with an average decrease value of $34.82 \%$, when rubber concrete was used as the material of transition section of road and bridge. Wu et al. [14] designed a lightweight backfilling method which cost less and avoided road closure. Field measurements showed that the method had a very significant effect in reducing settlement, the total land settlement decreased by $36 \%$ and the average settlement rate decreased by $40 \%$. Luo et al. [15] applied the properties of Expanded Polystyrene (EPS) material to fill embankment and found that the use of EPS material could greatly reduce the foundation pressure and settlement of pavement and increase the strength and had a good stability. Lightweight materials have been widely applied in the differential settlement treatment of transition section of road and bridge. Foam concrete is a very good lightweight material. It is a kind of concrete and has been applied in building and garden construction. Foam concrete with low thermal conductivity, good heat insulation effect, moderate sound absorption capacity and low elastic modulus plays an important role in solving the settlement difference problem of transition section of bridge and road.

In this study, foam concrete was applied to deal with the settlement difference problem. In order to improve the material properties, a high-strength foam concrete was designed, and the good strength and stability of the material were proved by the analysis of mechanical properties. It should be further popularized in settlement difference treatment.

\section{METHOD OF BACK FILLING BEHIND ABUTMENT WITH FOAM CONCRETE}

A $\mathrm{n}$ interchange in Sichuan province, China, has poor bearing capacity because of powder sand layer in foundation. There was problem of differential settlement in the transition of road and bridge. Back filling behind abutment with foam concrete was planned (Figure 1). The technical standards were wet density of $0 \sim 80 \mathrm{~cm}$ road base $\leqq 600 \mathrm{~kg} / \mathrm{m}^{3}$, and strength after 28 days $\geqq 0.6 \mathrm{MPa}$; wet density of $80 \mathrm{~cm}$ above road base $\leqq 650 \mathrm{~kg} / \mathrm{m}^{3}$, strength after 28 days $\geqq 0.8 \mathrm{MPa}$, and fluidity was $180 \mathrm{~mm}$.

\section{Manufacturing of high-strength foam concrete}

Raw materials used in the experiment included P.O52.5 ordinary Portland cement (Pangu Group, China), GS-1 foaming agent (Guansheng Civil Engineering Technology Co., Ltd., China), silicon ash (Shunde Ruitong Chemical Engineering Co., Ltd., China), grade I fly ash (Xiangtan Power Plant, China), S95 slag (Shaogang Jiayang Novel Material Co., Ltd., China) and polycarboxylene based superplasticizer.

The preparation method of foam concrete was as follows. Firstly the diluted foaming agent was stored in a liquid storage pot, and the pressure was added to $0.5 \mathrm{MPa}$ using an air compressor. Foam was obtained by mixing air with foaming 
agent (Figure 2). Cement, silica fume, slag and fly ash were weighed and taken and stirred by a stirrer for two minutes. Water reducer dissolved in water was poured to the mixing pot and stirred for three to five minutes. After foam was added, it was mixed evenly immediately. The test specimen was obtained after casting. It was maintained in water at $80{ }^{\circ} \mathrm{C}$ for $48 \mathrm{~h}$ and maintained in a standard maintenance room for 28 days after cooling.

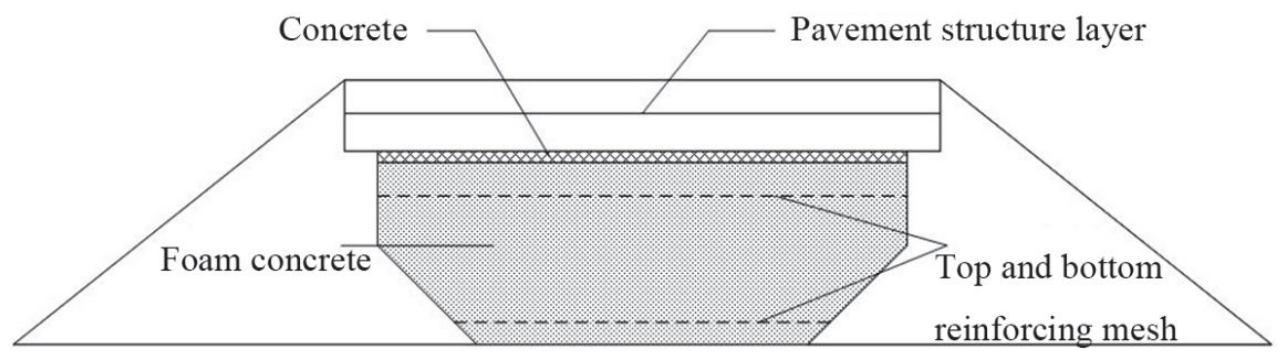

Figure 1: The cross section of foam concrete at the transition section of road and bridge.

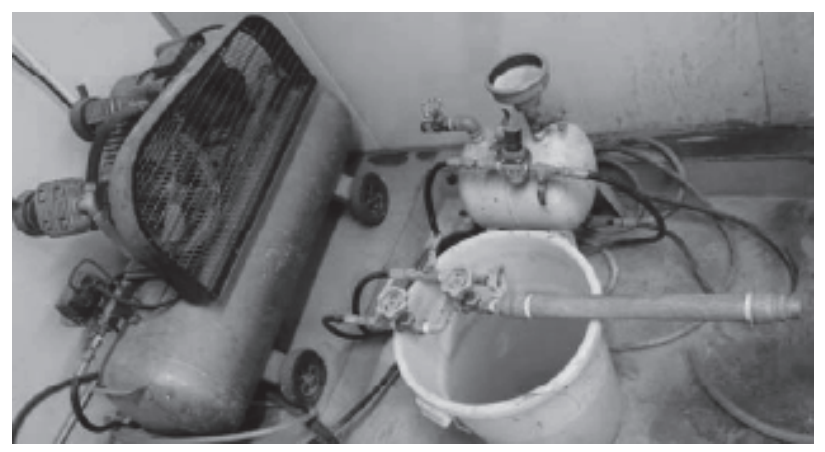

Figure 2: Air compressor and foaming device.

To obtain high-strength foam concrete, the proportion of different materials was adjusted to compare the properties of test specimens. Finally the optimal mix proportion of materials was obtained, as shown in Tab. 1.

\begin{tabular}{cc}
\hline Cement & 1 \\
Silicon ash & 0.3 \\
Slag & 0.1 \\
Fly ash & 0.4 \\
Water reducer & $1.5 \%$ \\
Water-binder ratio & 0.18 \\
\hline
\end{tabular}

Table 1: The mix proportion of materials.

Mineral admixtures in appropriate proportion formed grain composition in the paste, improving the density of the paste and adjusting the hole wall structure of concrete. The small water-cement ratio (0.6-0.65 usually) under the action of water reducer not only ensured the fluidity of the paste, but also improved the strength of concrete. The test results showed that the density of the specimens was $1319 \mathrm{~kg} / \mathrm{m}^{3}$ and the strength of the specimens was $25.8 \mathrm{MPa}$ after 28 days, which fully meet the requirements of back filling behind abutment.

\section{Back filling behind abutment with foam concrete}

Foam concrete was transported using pump pipe. The pouring gate of the pouring pipe was put outside the casting area and moved to the casting area after the output foam concrete was confirmed normal. The casting started from one end. Multiple pouring pipes worked at the same time. After reaching the predetermined height, the pump pipe was artificially lifted and slowly dragged after the surface was swept. The above actions were repeated until the casting finished. 
The following matters needed to be paid attention to in the construction process.

The casting area was cleaned before construction, and whether there was water on the foundation was checked. The casting area was covered in rainy days, and defoaming surface was shoveled. Casting stopped when rain was heavy. In winter, construction was allowed when the temperature was above $0{ }^{\circ} \mathrm{C}$; high temperature in the noon was avoided in summer. Long-time staying was avoided during casting. The pipe was washed if the staying time exceeded 10 min, and time of pipe washing was no less than $30 \mathrm{~min}$. Thin film was timely covered after casting for moisture preservation, and walking on the concrete was not allowed within seven days.

\section{ANALYSIS OF MECHANICAL PROPERTIES OF TRANSITION SECTION OF ROAD AND BRIDGE}

\section{Analysis of high-strength foam concrete}

T oad cycle test was performed on concrete test specimens in a size of $100 \mathrm{~mm} \times 100 \mathrm{~mm} \times 100 \mathrm{~mm}$ using an electro-hydraulic servo static/dynamic universal testing machine; the loading frequency was $6 \mathrm{~Hz}$, the amplitude value was $3 \mathrm{kN}$, and the mean value was $-4 \mathrm{kN}$. The times of load cycle increased from 0 to 1,200,000 times, with an increase of 200,000 each time. The changes of mechanical properties of the test specimen is shown in Figure 3 and 4.

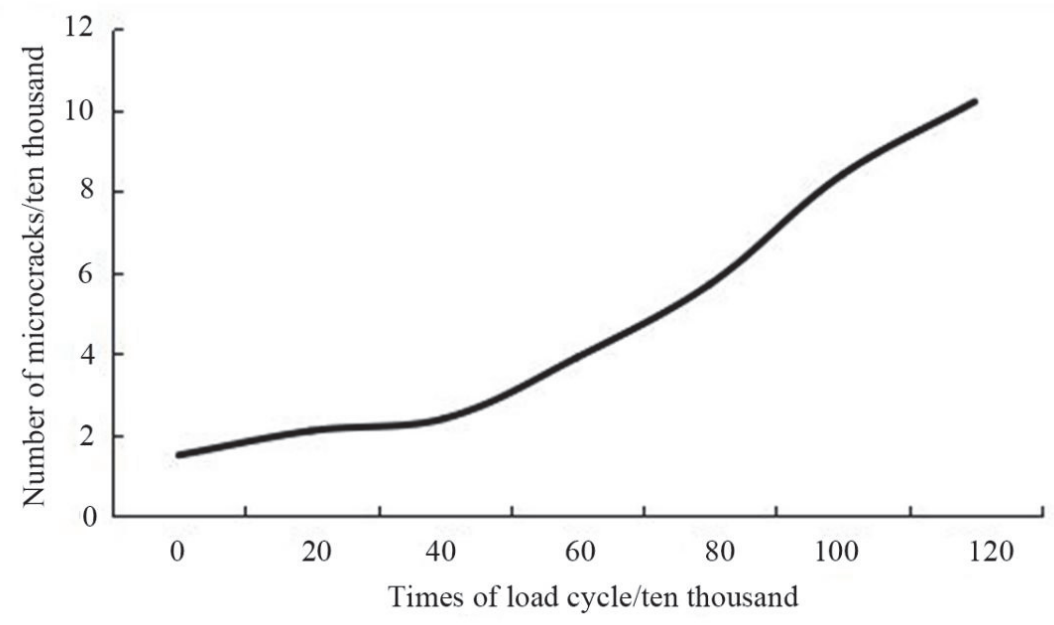

Figure 3: Curve of changes of number of micro cracks.
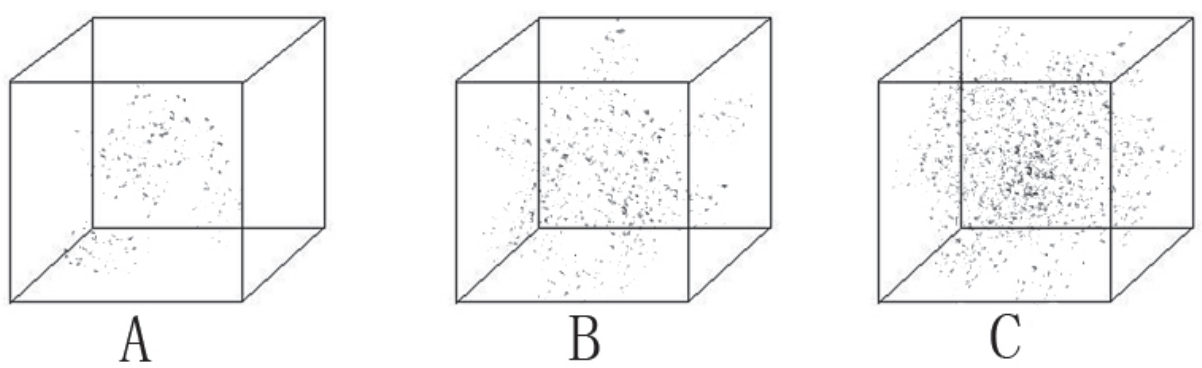

Figure 4: The sketch map of micro cracks (A: load cycles for 200,000 times; B: load cycles for 600,000 times; C: 1,000,000 times).

\begin{tabular}{cccccccccc}
\hline $\begin{array}{c}\text { Times of load cycles/ten thousand } \\
\text { times }\end{array}$ & 0 & 20 & 40 & 60 & 80 & 100 & 120 \\
Residual strength/MPa & 1.12 & 1.03 & 0.9 & 0.8 & 0.74 & 0.6 & 0.51 \\
& & & 7 & 9 & & 2 & \\
\hline
\end{tabular}

Table 2: Changes of residual strength. 
Figure 2 shows the number of micro cracks on the high-strength foam concrete specimens under the action of load cycle. The black spots in Figure 3 represented the micro cracks produced in the specimens. It was found that the number of micro cracks increased with the increase of load cycles, and the increase speed became higher and higher. After 1.2 million times (about 60 years of service), there were more than 100,000 micro cracks in the specimens, and the residual strength decreased from 1.12 $\mathrm{MPa}$ to $0.51 \mathrm{MPa}$, but no structural damage occurred. It could meet the basic requirements of use.

\section{Analysis of mechanical properties of transition section of road and bridge}

Establishment of finite element model

The model of transition section of road and bridge after processing of back filling behind abutment with high-strength concrete was established using finite element analysis method. Load such as house was ignored as the focus of the study is the changes of mechanical properties of the transition segment of road and bridge. Pavement, foam concrete and foundation adopted linear elastic model, and the others adopted Mohr-Coulomb plastic model. The structure of the model is shown in Figure 5.

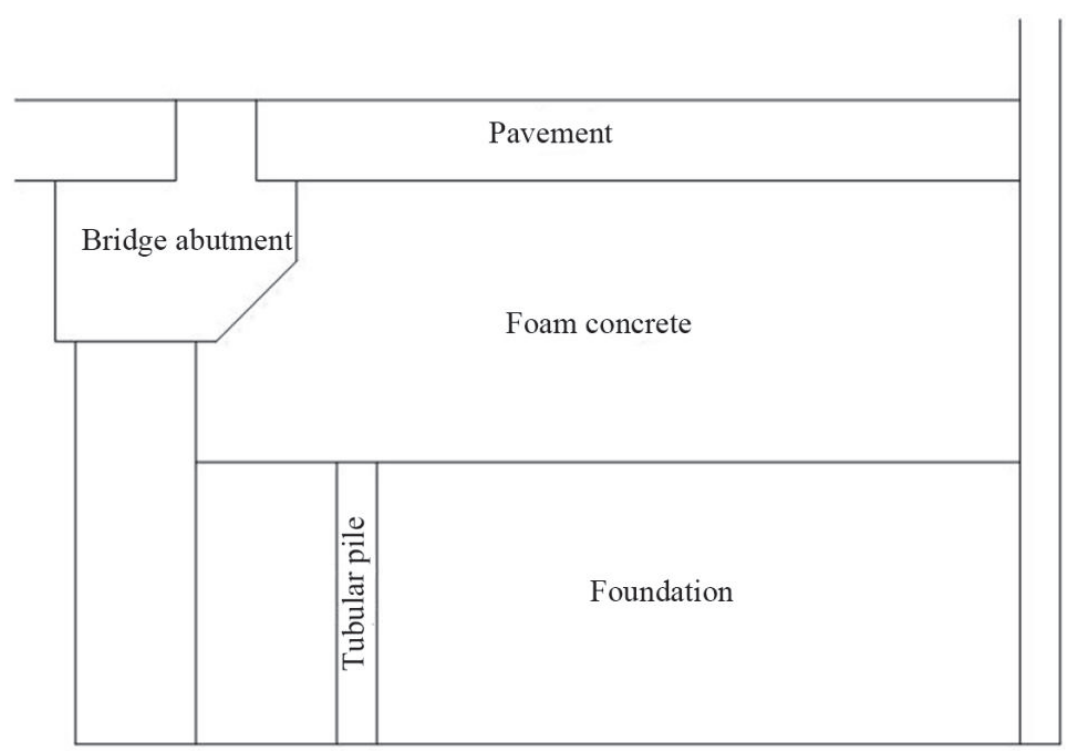

Figure 5: The sketch map of back filling behind abutment.

The parameters of the model are shown in Table 3.

\begin{tabular}{cccccc}
\hline Material & $\begin{array}{c}\text { Mass per unit } \\
\text { volume } \\
\left(\mathrm{kN} / \mathrm{m}^{3}\right)\end{array}$ & $\begin{array}{c}\text { Bulk modulus } \\
(\mathrm{MPa})\end{array}$ & $\begin{array}{c}\text { Shear modulus } \\
(\mathrm{MPa})\end{array}$ & $\begin{array}{c}\text { Cohesive } \\
\text { force }(\mathrm{kPa})\end{array}$ & $\begin{array}{c}\text { Internal } \\
\text { friction angle } \\
\left({ }^{\circ}\right)\end{array}$ \\
$\begin{array}{c}\text { High- } \\
\text { strength } \\
\text { foam } \\
\text { concrete }\end{array}$ & 6 & 290 & 226 & 366 & 5.1 \\
$\begin{array}{c}\text { Ordinary } \\
\text { concrete }\end{array}$ & 2 & 12500 & 12500 & 3180 & 54.9 \\
\hline
\end{tabular}

Table 3: Parameters related to the model.

The load of vehicle was simplified as impact surface source load, and the specific parameters of vehicle load are shown in Table 4. 


\begin{tabular}{cc}
\hline Wheel base $/ \mathrm{m}$ & $3.5+1.5$ \\
Gravity of front axle $/ \mathrm{kN}$ & $2 \times 30$ \\
Gravity of middle axle $/ \mathrm{kN}$ & $2 \times 120$ \\
Wheel base $/ \mathrm{m}$ & 1.8 \\
$\begin{array}{c}\text { ground } \\
\text { Length and width when front wheels touch the }\end{array}$ & $0.2 \times 0.3$ \\
Length and width when rear wheels touch the \\
ground
\end{tabular}

Table 4: Parameters of vehicle load.

Analysis of static base pressure

Figure 6 shows the change of base pressure of transition section of road and bridge under the deadweight pressure of soil body. It was found that the base pressure was small, about $10 \mathrm{kPa}$, around the bridge abutment, i.e., $0 \mathrm{~m}$ away from the expansion joint, and large when away from the bridge abutment, i.e., away from the expansion joint; the overall base pressure of the high-strength foam concrete was smaller than that of ordinary concrete; the base pressure of the highstrength foam concrete increased from $10 \mathrm{kPa}$ to $40 \mathrm{kPa}$, with the increase of the distance with the expansion joint; the base pressure of ordinary concrete increased from $10 \mathrm{kPa}$ to $80 \mathrm{kPa}$, which was significantly higher than that of the highstrength foam concrete. It indicated that the base pressure of the transition section of road and bridge was relatively small when the high-strength foam concrete was taken as the material of back filling behind abutment.

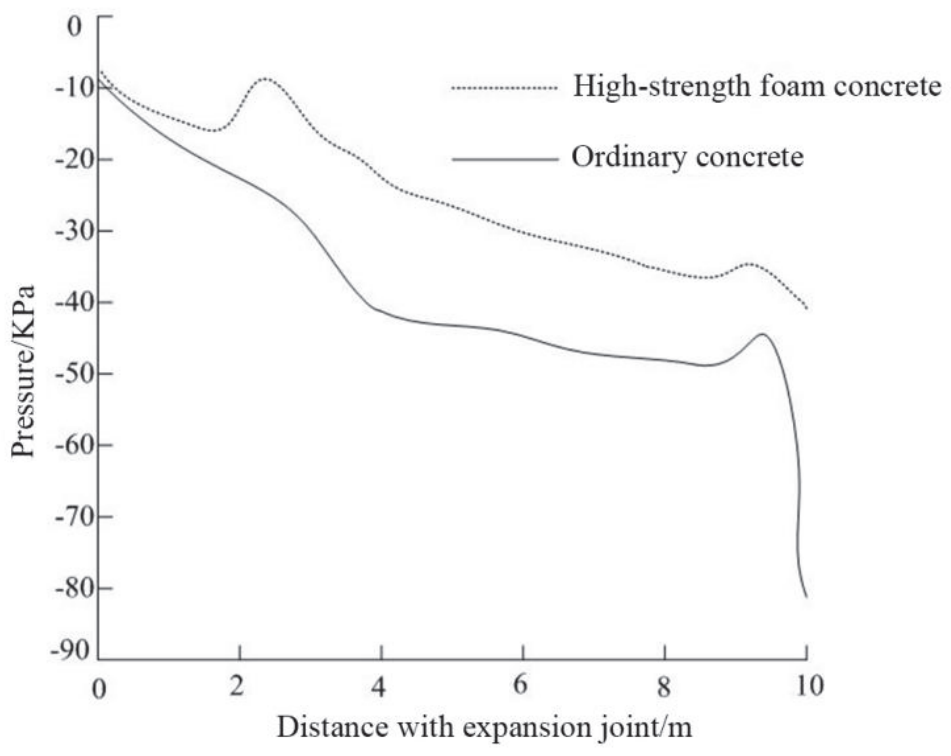

Figure 6: Analysis of change of base pressure.

Stress analysis under vehicle load

Fig. 7 shows that the curve of changes of vertical displacement of the transition section of road and bridge under vehicle load. The vertical displacement was the largest when vehicle load was exerted in $0.1 \mathrm{~s}$, and gradually decreased. The fluctuation of vertical displacement of ordinary concrete was significantly larger than that of the high-strength concrete. The maximum vertical displacement of ordinary concrete was $0.7 \mathrm{~m}$, and it tended to be stable at $0.35 \mathrm{~s}$. The vertical displacement of the high-strength foam concrete was smaller than $0.1 \mathrm{~m}$ and tended to be $0 \mathrm{~m}$ at $0.15 \mathrm{~s}$. It indicated that the stability of transition section of road and bridge was better when the high-strength foam concrete was taken as the material of back filling behind abutment. 


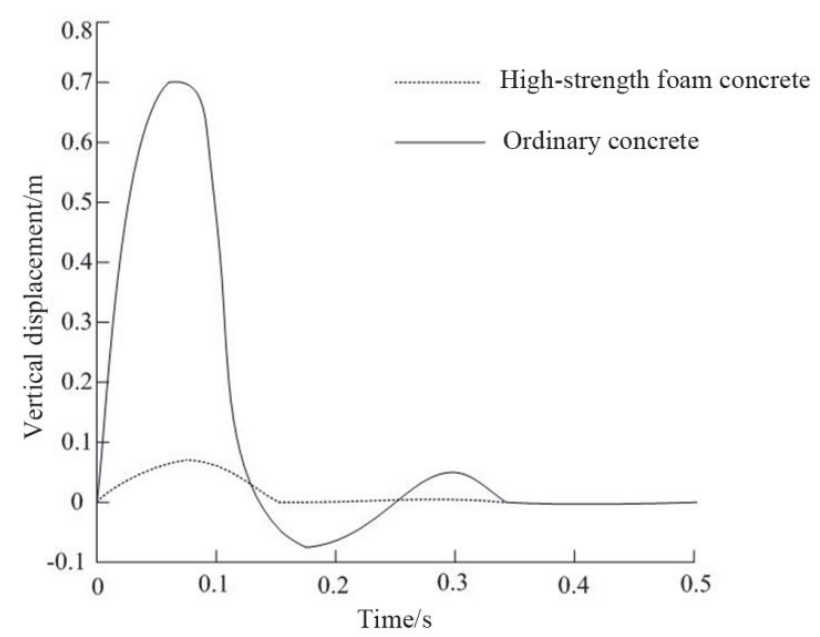

Figure 7: The curve of changes of vertical displacement.

Figure 8 shows the curve of changes of vertical stress. It was found that the vertical stress of ordinary concrete was significantly larger than that of the high-strength foam concrete and the maximum vertical stress was about $-45 \mathrm{kPa}$. The maximum vertical stress of the high-strength foam concrete was about $-40 \mathrm{kPa}$ and became $0 \mathrm{kPa}$ after $0.1 \mathrm{~s}$. The vertical stress of ordinary concrete was close to $0 \mathrm{kPa}$ after $0.1 \mathrm{~s}$, but still fluctuated, indicating that the damping effect of the high-strength foam concrete was better.

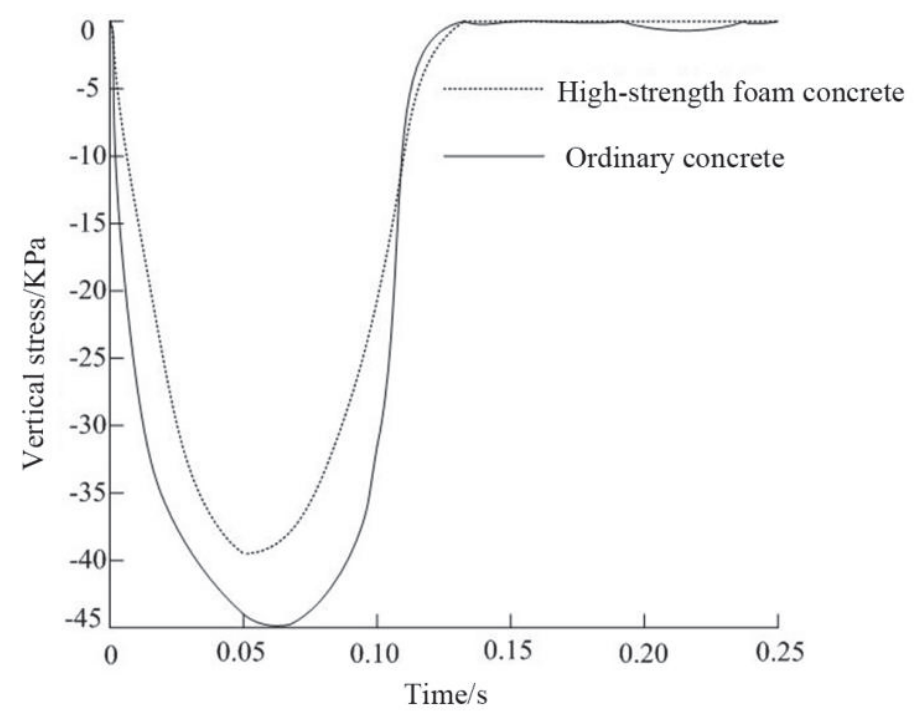

Figure 8: The curve of changes of vertical stress.

Analysis of ground surface settlement

Figure 9 shows the changes of settlement amount along the longitudinal center line of the road 300 days after the simulated transition segment of road and bridge opened to traffic. It was found that the settlement amount of the road beside bridgehead was large and increased gradually as time went by, the maximum settlement amount was about $0.04 \mathrm{~m}$, and the overall settlement of the road was stable, without bumping at bridge head. It showed that the back filling of highstrength foam concrete behind abutment was stable. 


\section{Discussion}

$\mathrm{T}$ he analysis of the high-strength foam concrete suggested that the material generated a large number of micro cracks under the action of load cycle, and the number of micro cracks increased significantly with the increase of load cycles; after 1 million 200 thousand cycles of loading, there were more than 100 thousand micro cracks in the specimen, and the residual strength was $0.51 \mathrm{MPa}$, but there was no structural damage. It indicated that it had a long service life and could fully meet the requirements of the transition section of road and bridge.

The analysis of the mechanical properties of the transition section of road and bridge suggested that the static base pressure of transition section of road and bridge which was processed by the high-strength foam concrete was about 40 $\mathrm{KPa}$, which was much smaller than that of ordinary concrete, indicating that the load on the transition section of road and bridge was small. Under the action of vehicle load, the mechanical properties of the high-strength foam concrete were better than those of ordinary concrete. The maximum vertical displacement of the high-strength foam concrete was less than $0.1 \mathrm{~m}$, and the maximum vertical stress value was about $-40 \mathrm{kPa}$, which was smaller than that of ordinary concrete, and it became stable in a relatively short time. It showed that the high-strength foam concrete could reduce the impact load of vehicle driving on the transition section of road and bridge and increase the service life of transition section of road and bridge.

In addition to better mechanical properties, back filling of foam concrete can also reduce side pressure on bridge abutments and improve bridge safety and service life. The construction difficulty is also low. It can effectively reduce settlement difference and avoid bridgehead jumping. Economically, in the construction using traditional materials, compactor will be used to compact the road surface, which takes long construction time, and moreover the cost of foundation treatment is also high. Dynamic compaction and rolling compaction are not needed for high-strength foam concrete, which shortens the construction period and production and transportation cost [16]; the cost of foundation treatment is low as it can be integrated directly with bridge abutment. In addition, although the price of high-strength foam concrete is higher than that of ordinary concrete, the comprehensive cost of high-strength foam concrete is significantly lower than the traditional material, and moreover it can be recycled. The use of recycled foam concrete can significantly reduce the treatment cost. In the aspect of environmental protection, the dust produced by the backfill materials such as lime soil and coal ash during the construction process is serious, which will cause great pollution to the surrounding environment. A large amount of dust may also lead to the production reduction of the surrounding farms. Foam concrete can effectively avoid dust pollution during construction and reduce the impact of construction on the environment, and will not cause adverse environmental consequences. In the aspect of durability, high-strength foam concrete can ensure a service time of at least 60 years of the transition segment of bridge and road, which can completely satisfy the requirement on age limit of road.

\section{CONCLUSION}

I $\mathrm{n}$ this paper, the mechanical properties of transition section of road and bridge based on high-strength foam concrete were analyzed, and the preparation and back filling method of high-strength foam concrete were briefly introduced. The mechanical analysis suggested that the high-strength foam concrete had better strength and longer service life. Compared with ordinary concrete, the high-strength foam concrete had smaller base pressure and structure load. Moreover its vertical displacement and stress under the action of vehicle load were both small. Therefore it has good vibration and energy absorption effects. It is an ideal material for back filling behind abutment and deserves further promotion.

\section{REFERENCES}

[1] Kaewunruen, S. and Mirza, O. (2017). Hybrid discrete element - finite element simulation for railway bridge-track interaction, Mater. Sci. Eng. Conf. Ser., pp. 012016. DOI: 10.1088/1757-899X/251/1/012016.

[2] Hu, C., Qiang, L., Liang, Z., et al. (2014). Test analysis of vibration characteristics of high-speed railway on CRTS II slab ballastles strack bridge-subgrade transition, J. Vib. Shock, 33(1), pp. 81-88. 
[3] Yan, W., Deng, L. and Yin, X. (2016). Allowable slope change of approach slabs based on the interacted vibration with passing vehicles, KSCE J. Civil Eng., 20(6), pp. 2469-2482. DOI: 10.1007/s12205-015-0466-1.

[4] (2016). Impact factors for fatigue design of steel i-girder bridges considering the deterioration of road surface condition, J. Bridge Eng., 21(5), pp. 04016011.

[5] Zhang, J., Zheng, J.J., Zhao, D.J., et al. (2016). Field study on performance of new technique of geosyntheticreinforced and pile-supported embankment at bridge approach, Sci. China Technol. Sc., 59(1), pp. 162-174. DOI: $10.1007 /$ s11431-015-5995-9.

[6] Huang, C.F., Li, Q., Wu, S.C., et al. (2017). Application of the Richards Model for Settlement Prediction Based on a Bidirectional Difference-Weighted Least-Squares Method, Arab. J. Sci. Eng., (2), pp. 1-9. DOI: $10.1007 /$ s13369-017-2909-0

[7] Li, H.L., Jin, C.Z., Yang, C.F., et al. (2014). Research on the Stress-Strain Law of Abutment Approach Embankment Filled with Liquid Fly Ash, Adv. Mater. Res., 1065-1069, pp. 536-539. DOI: 10.4028/www.scientific.net/AMR.1065-1069.536.

[8] Yasrobi, S.Y., Ng, K.W., Edgar, T.V., et al. (2016). Investigation of approach slab settlement for highway infrastructure, Transp. Geotech., 6, pp. 1-15. DOI: 10.1016/j.trgeo.2015.12.002.

[9] Xiang, Y.Q., Yun, S., Jin, F.G., et al. (2010). Case study of the deep-seated concrete slab for settlement control at bridge approach embankment, J. Harbin Instit. Tech., 42(1), pp. 158-162. DOI:10.1007/978-3-642-04460-1_124.

[10] Greco, F. and Lonetti, P. (2018). Numerical formulation based on moving mesh method for vehicle-bridge interaction, Adv. Eng. Softw., 121, pp. 75-83. DOI: 0.1016/j.advengsoft.2018.03.013.

[11] Lonetti, P., Pascuzzo, A. and Davanzo, A. (2016). Dynamic behavior of tied-arch bridges under the action of moving loads, Math. Probl. Eng., 2016, pp. 1-17.

[12] Sun, Y., Xiang, Y.Q., Guo, D.M., et al. (2010). Analysis of the Deep-Seated Concrete Slab for Settlement Control at Bridge Approach Embankment, Adv. Environ. Geotech. Springer Berlin Heidelberg, pp. 935-939. DOI:10.1007/978-3-642-04460-1_124.

[13] Liu, X., Liu, P., Wang, Q., et al. (2016). Feasibility Analysis on Application of Modified Concrete Contains Rubber Powder of Straddle Type Monorail Train Waste Tire, Proc. Environ. Sci., 31, pp. 804-811. DOI: $10.1016 /$ j.proenv.2016.02.078.

[14] Wu, Y.D., Zeng, C.C., Liu, J., et al. (2016). Measured Settlement of Highways Improved by Lightweight Backfilling Without Road Closure, Arab. J. Sci. Eng., 41(10), pp. 1-8. DOI:10.1007/s13369-015-2017-y.

[15] Luo, Y.H., Hu, H.Y., Huang, Z.X., et al. (2014). Characteristics of EPS Materials and the Application in Road and Bridge Projects, Appl. Mech. Mater., 501-504, pp. 1418-1423. DOI:10.4028/www.scientific.net/amm.501-504.1418.

[16] Amran, Y.H.M., Farzadnia, N. and Ali, A.A.A. (2015). Properties and applications of foamed concrete; a review, Constr. Build. Mater., 101(Part 1), pp. 990-1005. DOI:10.1016/j.conbuildmat.2015.10.112. 